\title{
Mitochondrial trifunctional protein deficiency
}

INSERM

\section{Source}

INSERM. (1999). Orphanet: an online rare disease and orphan drug data base.

Mitochondrial trifunctional protein deficiency. ORPHA:746

Mitochondrial trifunctional protein (TFP) deficiency (TFPD) is a disorder of fatty acid

oxidation characterized by a wide clinical spectrum ranging from severe neonatal

manifestations including cardiomyopathy, hypoglycemia, metabolic acidosis, skeletal

myopathy and neuropathy, liver disease and death to a mild phenotype with peripheral

polyneuropathy, episodic rhabdomyolysis and pigmentary retinopathy.. 